\title{
Farmers' Perceptions and Adaptations to Climate Change in Sub-Sahara Africa: A Synthesis of Empirical Studies and Implications for Public Policy in African Agriculture
}

\author{
James Sharka Juana ${ }^{1}$, Zibanani Kahaka ${ }^{1} \&$ Francis Nathan Okurut ${ }^{1}$ \\ ${ }^{1}$ Department of Economics, University of Botswana, Gaborone, Botswana \\ Correspondence: James Sharka Juana, Department of Economics, University of Botswana, Gaborone, Botswana. E-mail: \\ jamessjuana@yahoo.com
}

Received: January 10, 2013

Accepted: February 20, 2013 Online Published: March 15, 2013

doi:10.5539/jas.v5n4p121

URL: http://dx.doi.org/10.5539/jas.v5n4p121

\begin{abstract}
The problem of climate change in Africa has the potential of undermining sustainable development efforts if steps are not taken to respond to its adverse consequences. This study reviews existing and available literature on farmers' perceptions and adaptations to climate change in sub-Sahara Africa.

It is evident that the majority of farmers in sub-Sahara Africa are aware of warmer temperatures and changes in precipitation patterns. To respond to these changes, farmers have adopted crop diversification, planting different crop varieties, changing planting and harvesting dates to correspond to the changing pattern of precipitation, irrigation, planting tree crops, water and soil conservation techniques, and switching to non-farm income activities. Years of farming experience, household size, years of education, access to credit facilities, access to extension services and off-farm income are among the signicant determinants of adopting climate change adaptation measures.

To enable sub-Sahara African farmers to develop more effective climate change adaptationstrategies,there is the need for African governments to support farmers by providing the necessary resources such as credit, information and extension workers to train farmers on climate change adaptation strategies and technologies, and investing in climate resilient projects like, improving on existing or building new water infrastructure and building climate change monitoring and reporting stations.
\end{abstract}

Keywords: climate change, farmers' perceptions, adaptations, temperature, precipitation/rainfall

\section{Introduction}

The evidence that climate change will adversely affect agriculture in sub-Sahara Africa has become a crucial challenge for sustainable development on the continent.This challenge is composed of the likely impacts on ecosystem services, agricultural production, and livelihoods. Generally, losses in the agriculture sector due to climate change has economy wide consequences, like loss in gross domestic output, a decline in the income/consumption of the most vulnerable population; hence, a general deterioration in households' welfare. To dampen the adverse consequences of climate change, there is a need for farmers to adopt different adaptation strategies.Adaptation to the adverse consequences of climate change could be viewed from two distinct perspectives; i) the awareness of the risks of climate change and their capacity to adapt to climate change and ii) how adaptation can be carefully planned and implemented to avoid the possibility of mal-adaptation (Food and Agricultural Organization [FAO], 2007). While the former can be enhanced by providing relevant information to the vulnerable population about the risk and consequences of climate change, the latter involves technical developments and government insurance, which are principally the responsibility of public agents, agribusiness and government (FAO, 2007).

However, the design and implementation of any climate change policy requires adequate knowledge about the level of vulnerability, the existing knowledge the population has about the risks they are exposed to, the adaptation practices adopted, the existing capacity to adapt and the perceived barriers to adaptation. To address these issues and concerns, there is a need for a comprehensive assessment of farmers' perceptions and adaptations to climate change in Africa. 
Many studies have been carried out in different countries to assess climate change vulnerability, adaptations and coping mechanisms and adaptation barriers. However, different countries have different exposures to the risks of climate change. There is a need to synthesize these different studies and compare differences in climate change impacts and adaptation in African countries. Therefore, this study documents the existing literature on the perceptions of farmers about, and adaptations to climate change in sub-Sahara Africa. Specifically, the study is designed to:

i. Assess the existing knowledge that farmers have on, and the different levels of climate change risks perceived by farmers in Africa.

ii. Explore the adaptation strategies farmers have already adopted to cope with the consequences of climate change.

iii. Identify the perceived barriers to climate change adaptation strategies.

iv. Analyse the socio-economic determinants of farmers' adaptations to climate change in Africa.

v. Recommend plausible policy interventions that match farmers, perceptions, experiences, adaptation strategies and coping mechanisms in Africa.

The next section discusses the general impact of climate change in Africa. Section three presents a documentation of the different empirical studies carried out in Africa. In section four, the paper presents a synthesis of the empirical findings and in section five it summarizes the general findings, makes conclusions and suggests some farm level and public policies that match farmers' experiences and capacities to adapt.

\section{The Impact of Climate Change in Africa}

Sub-Sahara Africa is among the most vulnerable continents or regions to climate change impacts, because the majority of the sub-Sahara African population lives in abject poverty, and are heavily dependent on rainfed agriculture for their economic and livelihood sustenance. Therefore, variations in rainfall patterns and temperature adversely impact their economic and social survival. Because the main long-term impacts includesignificant changes in rainfall patterns and temperature which affect agriculture, there is a projected significant reduction in food security; worsening water security; decrease in fish resources in large lakes due to rising temperature; increase in vector-borne diseases; rising sea level affecting low-lying coastal areas with large populations; and rising water stress (African Partnership Forum [APF], 2007).

\subsection{Trends in Climate Change in Africa}

The historical climate record for Africa shows warming temperature of approximately $0.7^{\circ} \mathrm{C}$ over most of the continent during the twentieth century; a decrease in rainfall over large portions of the Sahel (the semi-arid region south of the Sahara); and an increase in rainfall in east and central Africa. Over the twenty first century, this warming trend, and changes in precipitation patterns are expected to continue and be accompanied by a rise in sea level and an increased frequency of droughts and floods (Intergovernmental Panel for Climate Change [IPPC], 2001). The report shows an increase in temperature in all the regions of sub-Sahara Africa. The same source predicts an increase in precipitation of 2\% in West Africa and 7\% in East Africa, but a decrease of $4 \%$ in southern Africa.

However, other sources have predicted a general decrease in precipitation and water availability. For example, Shiklomanov (1997) shows that between 1970 and 1995, Africa has experienced a 2.8 times decrease in water availability, and that the average discharge of West African rivers has dropped by $40-60 \%$ since 1970 . Under SRES scenarios, Arnell (2004) projects that by the year 2025 about 370 million African people will experience increases in water stress, while about 100 million people are likely to experience a decrease in water stress by the year 2055, as a result of a likely increase in precipitation. In the Nile region, most scenarios of water availability estimate a decrease in river flow up to more than $75 \%$ by the year 2100 , with implications for agriculture and conflict (Nyong, 2005).

Severe droughts have been recorded for southern Africa. Over parts of southern Zimbabwe and south-eastern Botswana, rainfall amounts were as low as $10 \%$ of the average value during the rainy season of 1991/92. Droughts in southern Africa are mainly due to the result of the El Niño/Southern Oscillation (ENSO) phenomenon, the periodic warming of the tropical Pacific Ocean and related shifts in the atmospheric circulation which brings climatic disruption to many low latitude areas (Glantz, 1992). There is a historic link between the occurrence of ENSO events and droughts in southern Africa. The ENSO event of the early 1990s was unusual in that it continued for longer than usual. The drought conditions in southern Africa only eased slightly during the 1992/93 season, although by 1993/94 higher rainfall levels were experienced in the region (Hulme, 1994). 


\subsection{Key Climate Change Impacts in Africa}

The most vulnerable areas or sectors to climate change in Africa are water resources, agriculture, health, ecosystems and biodiversity, forestry and coastal zones.

"Overall, climate change presents a substantial challenge to regional agricultural development. From food security and nutrition to sustainable management of natural resources, climate change is a significant threat to the welfare of millions of the continents rural poor. If adequate measures are not taken to adapt to the adverse consequences of climate change in sub-Sahara Africa, the region will remain vulnerable to the widespread effects of climate change" (Food and Agricultural Organization [FAO], 2009). The same source predicts a loss of 2-7\% of GDP by 2100 in parts of sub-Sahara Africa; $2-4 \%$ and $0.4-1.3 \%$ in West and central Africa, and northern and southern Africa respectively (FAO, 2009). Arid and semi-arid land could expand in coverage by $60-80 \mathrm{M}$ ha. Fisheries will be particularly affected due to changes in sea temperatures that could decrease trends in productivity by $50-60 \%$ and that productivity in Africa will be further undermined by a reduction in fertile agricultural land available and an expansion in the coverage of low potential land (FAO, 2009).

Studies have shown that while agriculture is a primary climate change impact sector, other sectors in the economy are also impacted because of the induced effect from the agriculture sector. For example, Juana, Mangadi, and Strzepek (2012) show that $20 \%$ reduction in water availability in South Africa due to climate change will lead to a $12 \%$ decline in agricultural output. Because of the backward and forward linkages between agriculture and the other sectors of the economy, this $12 \%$ decline in agricultural output will lead to about $8 \%$ decline in gross sectoral output. Also, Juana, Makepe, and Mangadi (2012) show that a 10\% loss in agricultural output in Botswana due to drought will lead to about $8 \%$ decline in total sectoral output.

Studies have also shown that the impact of climate change or climate variability is not evenly spread among the different socio-economic household groups. For example, Juana, Mangadi, and Strzepek (2012) show that poor households in South Africa are the most vulnerable population group to climate change. Similar results are also recorded in Juana, Makepe, and Mangadi (2012). These studies show that the impact of climate change leads to general deterioration in households' welfare, but that poor or rural households who depend primarily on agriculture for their economic or livelihood sustenance are the most vulnerable population group.

The increase in temperature, especially in the summer months will lead to increased human death (Conway, 2008). Diseases carried by insects and other vectors are especially susceptible to the effects of climate change. For example, the geographical distribution and the rates of development of mosquitoes are highly influenced by temperature, rainfall and humidity. The anopheles mosquito that transmits malaria parasite has been observed in the central highlands of Kenya, where no malaria vectors have previously been recorded (Conway, 2008). Increased temperatures and more prolonged rainy seasons may extend the transmission period of the disease. In general, an extension of the range of malaria carrying mosquitoes and malaria into higher elevations, particularly above $1000 \mathrm{~m}$ is expected. There have been resurgences of malaria in the highlands of East Africa in recent years. Dengue, another mosquito borne disease is also likely to increase (Conway, 2008). In addition to the above impacts, climate change can have significant negative impacts on the natural environment including the loss of biodiversity and changes in ecosystem services and functions (Mwingira et al., 2011).

According to the Intergovernmental Panel for Climate Change [IPPC] (2007), any increase in global average temperature above the range of $1.5-2.5^{\circ} \mathrm{C}$ is likely to result in significant alterations in the structure, function and geographical ranges of ecosystems, which negatively influences species distribution and survival. In developing countries where the majority of the population has a greater dependence on natural-resource-based livelihoods, this can impact the socio-economic status of communities, hamper progress towards development goals and presentan overall threat to sustainable development (IPCC, 2007). Several species aroundAfrica are now affected by the combined impacts of climate factors and their interactions with otheranthropogenic stressors such as encroachment, land fragmentation and destruction of natural habitats. Together, climatic and non-climatic stressors may have considerable impacts on the ecosystems functions and on ecosystem services (Lovejoy, 2005). Other impacts include destruction of infrastructure like dams, roads, bridges, water and electricity distribution networks and coastal ecosystems. 


\section{Empirical Studies on Farmers' Perceptions and Adaptations to Climate Change in Africa}

The studies documented below present empirical findings on farmers' perceptions and adaptations to climate change in Africa.

Kurukulasuriya and Mendelson (2006) used the Multinomial Logit Model to analyse crop and livestock choice as climate change adaptation options in Burkina Faso, Cameroon, Ghana, Niger, Senegal, Egypt, Ethiopia and Kenya, South Africa, Zambia and Zimbabwe. The study on crop choice showed that crop choice is climate sensitive and farmers adapt to changes in climate by switching crops. The results of the choice models from the livestock study showed that farmers in warmer temperatures tend to choose goats and sheep as opposed to beef cattle and chicken. Goats and sheep can do better in dry and harsher conditions than beef cattle.

Maddison (2006) reports that perceptions about climate change showed that a significant number of farmers believe that temperature has already increased and that precipitation has declined for eleven African countries. Farmers with the greatest farming experience were more likely to notice changes in climatic conditions which according to the study are consistent with farmers engaging in Bayesian-updating of their prior beliefs. The study also reported that farmers' experiences, access to free extension services and markets are important determinants of adaptation.

Nhemachena and Hassan (2007) examined farmers' adaptation strategies in South Africa, Zambia and Zimbabwe. The study describes farmers' perceptions about long-term changes in temperature and precipitation, as well as various farm-level adaptation measures adopted, and barriers to adaptation. The results indicated that using different crop varieties, crop diversification, changing planting dates, switching from farm to non-farm activities, increased use of irrigation, and increased water and soil conservation techniques were the different adaptation measures employed by farmers in these countries. The study also reported that most farmers perceived long-term increase in temperature and that the region was getting drier, with changes in the timing of rains and frequency of droughts. The farmers reported that lack of credit facilities and information on adaptation options and insufficient inputs are the main barriers to adopting any climate change adaptation options. The results of the multivariate discrete choice analysis show that gender, years of farming experience, access to extension services, access to credit facilities and markets are the significant determinants of adaptations to climate change in the region.

Gbetibouo (2009) argues that farmers with access to extension services in South Africa are likely to perceive changes in the climate because extension services provide information about climate and weather. Consequently, awareness and perceptions of changes in climatic conditions shape action or inaction on the problem of climate change. In a similar study, Mertz, Mbow, Reenburg, and Diouf ( 2009) analysed farmers' perceptions of climate change and adaptations in the savanna zone of Senegal. The results of the study showed that farmers in this zone are aware of climate variability, and identified intensive wind and occassional excess rainfall as the most destructive climatic factors. They therefore attributed poor livestock health and reduced crop yield to these adverse climatic factors. However, the farmers also attributed crop failures and other perceived climate impacts to the political problems in the country.

In Ethiopia, Deressa, Hassan, Ringler, Alemu, and Yesuf (2008) analysed the determinants of farmers' choice of adaptation methods in the Nile Basin. Using cross-sectional data from a survey of farmers to illicit infromation on adaptation methods, the study found that the adaptation methods currently in place in the study area are; changing planting dates, using different crop varieties, planting tree crops, irrigation, soil conservation and not adapting. The farmers reported that the use of different crop varites was the most common adaptation method, while irrigation was the least common. They also reported that the reasons for not adapting are lack of information on climate change impacts and adaptation technologies, lack of financial resources, labour constraints and land shortages. The level of education, age, sex and household size of farmers were found to be significant determinants of adaptation to climate change in the study area. Also farmers in different agroecological settings employ different adaptation methods.

Fosu-Mensah, Vlek, and Manscheadi (2010) conducted a survey of 180 farmers in Sekyedumase District in the Ashanti Region of Ghana to investigate how they perceive long-term changes in temperature, rainfall and vegetation cover over the past twenty years. The survey also posed questions about adaptations and barriers to adaptations. The explanatory variables included households charateristics, years of farming experience, farm size, access to markets, access to extension services, access to credit/loans, land tenure and soil fertility. Main adaptation strategies reported by farmers are crop diversification and changing planting dates. Land tenure, soil fertility levels, access to extension services, access to credit and the community in which the farmers lived were found to be the significant determinants of their choice of adaptation measures farmers took. 
Acquah-de Graft and Onumah (2011) analyzed information collected from 185 farmers from western Ghana about their perceptions on, and adaptations to climate change in the region. While the majority of the farmers interviewed perceived increase in temperature and decreased precipitation as the climate change variables experienced in that region, only $18 \%$ of the respondents did not perceive any changes in the two climatic variables. While about $60 \%$ of the respondents reported the use of one or more adaptation methods, $40 \%$ did not adopt any adaptation measures. The main adaptation measures adopted by farmers include changing planting dates, using different crop varieties, planting tree crops, practising irrigation, soil conservation and water harvesting. The farmers identified lack of information on climate change impacts and adaptation options, lack of access to credit, access to water, high cost of adaptation, insecure property rights and lack of access to sufficient farm inputs as the main barriers to the adoption of any adaptation measure. The probit analysis indicated that the significant determinants of adaptation to climate change are age, gender, years of education, years of farming experience, own farm land and other income generating activities.

Nyanga, Johnson, Aune, and Kahinda (2011) interviewed 469 farmers from 12 districts in Zambia to elicit information on their perceptions of climate change impacts in the country. Most farmers reported that they have perceived increase in the duration of the cold season, no change in the duration of the hot season and a reduction in the rainy season's duration. Also, farmers perceived an increase in the frequency of droughts and floods. The study revealed that crop diversification, conservation agriculture and gardening are the common adaptation measures used by arable farmers, while increasing livestock diversity and seeking support from veterinary officers are the measures taken by pastoral farmers.

In Osun State, Nigeria, Sofoluwe, Tijani, and Baruwa (2011) surveyed 100 farmers to gather information on their perceptions about changes in temperature and precipitation. The study used the Multinomial Logit Model to analyze the factors that determine farmers adoption of various climate change adaptation measures. The results show that more than $75 \%$ of the respondents were aware of increase in temperature and precipitation in the region. The farmers reported that late planting, irrigation, soil conservation, planting different crop varieties are the common adaptation strategies used, and that lack of information on climate change impacts and access to credit, labour shortages, shortage of land and poor potential for irrigation are the barriers to adapting to the perceived changes in climatic conditions. The regression results showed that livestock ownership, access to loans, off farm income generation, gender and household size are the significant determinants of adapting to climate change impacts.

Mandleni and Anim (2011) used information collected from 500 livestock farmers who participated in extension training courses in the eastern cape of South Africa. The information included farmers' perceptions about climate change in the province and the adaptation measures they have considered appropriate. The analytical results show that about $86 \%$ of the farmers were aware of increase in temperature, and that weather conditions in the province was dominated by drought. About $83 \%$ of the respondents reported that harsh weather conditions led to the reduction in cattle numbers.

Yesuf, Di Falco, Deressa, Ringler, and Kohlin (2008) analysed the impact of climate change and adaptation on food production in Ethiopia. The authors used two separate models to examine the factors influencing farmers' decision to adapt to perceived climate change impacts. The results of the study revealed that changing crop variety, soil and water conservation, water harvesting, planting of trees and changing planting and harvesting dates are the choices of adaptation measures adopted by the farmers. Among these methods of adaptation, planting trees was themeasure adopted by most farmers. However, about $42 \%$ of the farmers did not use any adaptation method for climate change impacts. The study also showed that household wealth represented by farm and non-farm income and livestock ownership, increases the likelihood of climate change awareness and adaptation.

In south western Nigeria, Apata, Samuel, and Adeola (2009) analysed arable food crop farmers' perceptions about climate change and adaptation strategies. The study administered structured questionnaire and held Focus Group Discussions. From the 350 valid respondents the authors employed the Binomial Logit analysis to explore the characteristics that best explain variation in the measures of attitudes of the indigent perception and adaptations to climate change, and factors that influence such decisions. Focus Group Discussions revealed that farmers had experienced a change in climatic conditions. About $89 \%$ indicated that there has been a significant increase in temperature, $72 \%$ perceived higher evapo-transpiration rates, $70 \%$ experienced the spread of agricultural pests and weeds on crop land, $68 \%$ indicated that there has been violent rain and hailstorms, and $65 \%$ experienced delayed rainfall and early cessation. As a result of low rainfall and increased temperature, farmers seem to be abandoning mono-cropping for mixed cropping and mixed crop-livestock systems. Moreover, farming experience and access 
to education were found to promote adaptation. This implies that educating farmers to improve their awareness of potential benefits of adaptation is an important policy measure.

Nzeadibe, Egbule, Chukwuone, and Agu (2011) used descriptive statistics (group interviews and household surveys) to analyse farmers' perception of climate change governance in the Niger Delta as well as to examine the factors that limit adaptations to climate change in the study area. The respondents believe that the involvement of the state through legislature is very important in aiding climate change adaptation. The study showed that the majority of farmers in the study area were not aware of climate change consequences and the effectiveness of policies and programmes by government regarding climate change. Furthermore, the main factors that prevent farmers from adapting to climate change impacts were found to include: information asymmetry, irregularities of extension services, poor government attention to climate problems, inability to access available information and improved crop varieties/seeds, ineffectiveness of indigenous methods, no subsidies on planting materials, limited knowledge on adaptation measures, low institutional capacity, and absence of government policy on climate change.

Akponikpè, Johnson, and Agbossou (2010) conducted a survey of 234 farmers in 78 villages in Benin, Burkina Faso, Ghana, Niger and Togo. The study used statistical tools to analyse farmers' responses to the administered questionnaire. Most of the respondents reported that there has been a decrease in rainfall and a significant increase in temperature over the years. The pattern of rainfall has changed, with delayed rains and early cessation; and that there has been an increase in the number of hot days. However, there were variations in these reports according to differences in agro-climatic zones.The farmers reported that they have adopted water and soil conservation strategies to deal with the prolonged lack of rain. Most farmers also delay planting to adapt to the delayed rains.

The socio-economic team of Advancing Capacity to support Climate Change Adaptations [ACCCA] (2010) employed a Multivariate Probit model to analyse data from a survey of 160 farm households in Tigray, northern Ethiopia. The main aim of this study is to analyse the factors influencing the farmers' decision to adapt. The findings indicated that the most common adaptation strategies include: use of different crop varieties, soil and water conservation, changing planting dates, use of external fertilizer, borrowing lost local crops from community, and using short duration crops. Extension service, livestock ownership by female farmers, access to climate change information and the observed change in temperature have positive and substantial impact on adaptation to climate change.

de Wit (2006) investigated the ability of farmers to detect and adapt to climate change. The study collected data from Burkina Faso, Cameroon, Egypt, Ethiopia, Ghana, Kenya, Niger, Senegal, South Africa and Zambia on the natural trends in temperature and precipitation, perceived barriers to adaptation, and socio-economic factors influencing adaptation in each country. A significant number of farmers across the 11 countries indicated that average temperatures have increased while precipitation has decreased.A significant minority reported that they have experienced a change in the timing of the rains. Adaptation strategies across these countries varied from planting varieties of the same crop, changing the planting dates, increased use of irrigation, to water and soil conservation techniques. However, in some of the countries farmers indicated that they have made no adjustments to their agricultural practices. What the farmers considered as barriers to adaptation also differed among the countries. These barriers included lack of credit, lack of access to water and appropriate seed as well as lack of information about the weather or long-term climate change.

Acquah de Graft (2011) assessed farmers' perceptions and adaptation to climate change as well as the socioeconomic determinants of willingness to pay for climate mitigation policies in Ghana. Through the use of descriptive statistics and the Logit Model the study results indicated that: $60 \%$ reported that there has been a noticeable increase in temperature and $49 \%$ reported a decrease in rainfall. On the other hand, the farmers' level of adaptation was found to be relatively high with majority of the farmers' stating that: planting different varieties of crops, changing planting dates, and soil and water conservation are the main adaptation measures taken to cope with climate change. The farmers reported that insufficient access to inputs, lack of knowledge about other adaptation options and no access to water were the main climate change adaptation constraints. Other barriers included lack of credit and lack of information about climate change, high cost of adaptation and insecure property rights. Furthermore, results revealed high level of willingness to pay for mitigation policies among the farmers. Years of farming experience, ownership of farm land, farm size and other income are significant predictors of the probability to pay for climate change mitigation policy.

Gandure, Walker, and Botha (2012) investigated how farmers perceived and adapted to climate change impacts in a South African rural community. The study was carried out in Gladstone village in Thaba Nchu district, where the authors had 13 Focus Group Discussions with farmers representing various land and farming types in Gladstone. 
The discussion centred on how they perceived climate change variables, how they have adapted to changes in the perceived climatic conditions, and the factors inhibiting adaptations to climate change in the study area.

The analysed results show that most farmers have perceived increase in temperature, and that summer temperatures were warmer, while winter temperatures were colder. Warmer temperatures are associated with high evaporation and increased crop water requirements.

The farmers also reported that there has been a perceived decrease in rainfall or precipitation. They particularly noticed delayed rainfall and early cessation. They reported that weeds, insects and worms have the strongest influence on their livelihoods. Generally, education and awareness about climate change impacts and therefore coping capacities were found to be very low among most farmers partly due to weak institutional coordination and support. The analysis of livelihood risks, which was done through scoring and ranking of responses, shows that the impact of weeds, insects and worms pose the highest risk to farmers in Gladstone. Poor security is the second most important factor followed by poor access to markets. Rainfall variability ranks fourth, while old age, poor health and extreme temperatures rank fifth, sixth and seventh respectively (Gandure et al., 2012). The barriers to adaptations to climate change included lack of access to early warning information and unreliability of seasonal forecast. Farmers also reported that lack of access to adequate cropland was a barrier to adapting to climate change.

Table 1 in the appendix provides a summary of the empirical findings on farmers' perceptions and adaptations to climate change impacts in sub-Sahara Africa.

Table A1. Summary of empirical studies on farmers' perceptions and adaptations to climate change in sub-Sahara Africa

\begin{tabular}{|c|c|c|}
\hline Author & $\begin{array}{l}\text { Region/Coun } \\
\text { try }\end{array}$ & Objective \& Methodology \\
\hline $\begin{array}{l}\text { Kur } \\
\text { ukul } \\
\text { asuri } \\
\text { ya \& } \\
\text { Men } \\
\text { dels } \\
\text { on } \\
(200 \\
6)\end{array}$ & $\begin{array}{l}\text { Burkina Faso, } \\
\text { Cameroon, } \\
\text { Ghana, Niger, } \\
\text { Senegal, Egypt, } \\
\text { Ethiopia and } \\
\text { Kenya, South } \\
\text { Africa, Zambia, } \\
\text { Zimbabwe }\end{array}$ & $\begin{array}{l}\text { Used the Multinomial Logit } \\
\text { Model to analyse crop \& } \\
\text { livestock choice of climate } \\
\text { change } \\
\text { adaptation options }\end{array}$ \\
\hline $\begin{array}{l}\text { Mad } \\
\text { diso } \\
\mathrm{n} \\
(200 \\
6)\end{array}$ & Africa & $\begin{array}{l}\text { Used the Heckman's sample } \\
\text { selectivity Probit Model to } \\
\text { analyse farmers' perceptions } \\
\text { about climate change and } \\
\text { adaptation measures. }\end{array}$ \\
\hline
\end{tabular}

Burkina Faso, De Cameroon, Wit Egypt, Ethiopia, studyinvestigated the ability (200 Ghana, Kenya, of farmers to detect and adapt 6) Niger, Senegal, South Africa and Zambia to climate change Major Findings

- Farmers adapt to changes in climate by switching crops.

- Farmers in warmer temperatures choose goats and sheep as opposed to beef cattle and chicken. Goats and sheep can do better in dry and harsher conditions than the latter.

-farmers believe that temperature has already increased and that precipitation has declined.

-farmers' experiences, access to free extension services and markets are important determinants of adaptation.

-average temperatures have increased \& precipitation has decreased.

-adaptation strategies: planting varieties of the same crop, changing the planting dates, increased use of irrigation, water and soil conservation techniques.

-barriers to adaptation included lack of credit, lack of access to water and appropriate seed as well as lack of information about the weather or long-term climate change.

Nhe mac hena \& Zambia and Hass Zimbabwe an $(200$
Used the Multinomial Logit Model to assess farmers perceptions, adaptation measures, \& barriers to adaptation -found that there is long-term increase in temperature and that the region was getting drier.

- adaptation measures :using different crop varieties, crop diversification, changing planting dates, switching from farm to non-farm activities, increased use of irrigation, increased water and soil conservation 


\section{7)}

Yes

uf et

al Ethiopia

(200

8)

Dere

ssa

et al Ethiopia

(200

8)

Mert Senegal

$\mathrm{z}$ et

al

(200

9).

Apat Nigeria

a et

al

(200

9)
Applied descriptive statistics \& econometric regression analysis to examine the impact of climate change and adaptation on food production

Applied discrete choice models on a cross-sectional household survey data to investigate and analyse the determinants of farmers' choice of adaptation methods

Used interviews, household survey data to

analyse farmers' perceptions of climate change and adaptations

Applied the Binomial Logit Model to analyse arable food crop farmers' perceptions about climate change and adaptation strategies.

\section{techniques.}

-barriers to adaptation: lack of credit facilities and information on adaptation options and insufficient inputs.

-Adaptation measures: changing crop variety, soil and water conservation, water harvesting, planting of trees and changing planting and harvesting periods

-adaptation methods: changing planting dates, using different crop varieties, planting tree crops, irrigation, soil conservation.

-adaptation barriers: lack of information on climate change impacts and adaptation technologies, lack of financial resources, labour constraints and land shortages.

-level of education, age, sex and household size of farmers significantly increased the probability of adaptation.

-identified intensive wind and occasional excess rainfall as the most destructive climatic factors.

-as a result there is poor livestock health and reduced crop yield.

-Farmers perceived a significant increase in temperature, spread of agricultural pests and weeds on crop land, violent rain and hailstorms, delayed rainfall and early cessation.

-adaptation methods: mono-cropping abandoned for mixed cropping i.e. mixed crop-livestock systems.

-farming experience and access to education were found to promote adaptation.

- adaptation strategies: crop diversification and changing planting dates.

- Land tenure, soil fertility levels, access to extension services, access to credit and the community in which the farmers lived were found to be the significant determinants of their choice of adaptation measures.

-farmers reported to have experienced a decrease in rainfall and a significant increase in temperature over the years.

-water and soil conservation strategies were adopted to deal with the prolonged lack of rain. Most farmers also delay planting to adapt to the delayed rains.

- adaptation strategies: use of different crop varieties, soil and water conservation, changing planting dates, use of external fertilizer, borrowing lost local crops 
(201

0)

Acq Ghana
uah-
de
Graf
t \&
Onu
mah
$(201$
$1)$

Nya Zambia
nga
et
al.(2
$011)$

Sofo Nigeria

luwe

et al.

(201

1) farmers' decision to adapt to climate change impacts.

Applied the Binomial Probit analysis to analyse farmers perceptions and adaptation to climate change, and the barriers to adaptation options.

Interviewed farmers to elicit information on farmers perceptions of climate change impacts in the country and the adaptation measures adopted by these farmers.

Applied the Multinomial Logit Model to analyze the factors that determine farmers adoption of various climate change adaptation measures.

Descriptive Statistics were used to examine farmers perceptions about climate change.

Descriptive statistics (group interviews and household surveys) were used to analyse farmers' perception of climate change governance \& the barriers to adaptation. from community, and using short duration crops.

-Extension service, livestock ownership by female farmers, access to climate change information and the observed change in temperature have positive and substantial impact on adaptation to climate change.

-adaptation measures: changing planting dates, using different crop varieties, planting tree crops, practising irrigation, soil conservation and water harvesting.

-barriers to adaptation: lack of information on climate change, lack of access to credit, access to water, high cost of adaptation, insecure property rights and lack of access to sufficient farm inputs.

- determinants of adaptation to climate change were found to consist of age, gender, years of education, years of farming experience, own farm land and other income generating activities.

-farmers observed an increase in the duration of the cold season, no change in the duration of the hot season and a reduction in the duration of the rainy season's, an increase in the frequency of droughts and floods.

- crop diversification, conservation agriculture and gardening are the common adaptation measure used by arable farmers, while increasing livestock diversity and seeking support from veterinary officers are the measures taken by pastoral farmers.

- farmers reported that late planting, irrigation, soil conservation, planting different crop varieties are the common adaptation strategies used.

-lack of information on climate change impacts and access to credit, labour shortages, shortage of land and poor potential for irrigation are the barriers to adaptations.

-livestock ownership, access to loans, off farm income, gender and household size are the significant determinants of adapting to climate change.

- farmers perceived an increase in temperature, weather conditions in the province was dominated by drought.

- respondents believe that the involvement of the state through legislature is very important in aiding climate change adaptation.

- most farmers in the study area not aware of climate change consequences and the effectiveness of policies and programmes by government regarding climate change.

-Barriers to adaptation: information asymmetry, irregularities of extension services, poor government 


\begin{tabular}{|c|c|}
\hline $\begin{array}{l}\text { Acq Ghana } \\
\text { uah } \\
\text { de } \\
\text { Graf } \\
\text { t } \\
\text { (201 } \\
\text { 1) }\end{array}$ & $\begin{array}{l}\text { Applied Descriptive } \\
\text { Statistics and the Binomial } \\
\text { Logit Model to analyse } \\
\text { farmers' perceptions and } \\
\text { adaptation to climate change, } \\
\text { and the socioeconomic } \\
\text { determinants of willingness } \\
\text { to pay for climate mitigation } \\
\text { policies. }\end{array}$ \\
\hline
\end{tabular}

Gan South Africa dure et al. (201 2) attention to climate problems, inability to access available information and improved crop varieties/seeds, ineffectiveness of indigenous methods, no subsidies on planting materials, limited knowledge on adaptation measures, low institutional capacity, and absence of government policy on climate change.

- planting different varieties of crops, changing planting dates, and soil and water conservation are the main adaptation measures.

-barriers to adaptation: insufficient access to inputs, lack of knowledge about other adaptation options and no access to water, lack of credit and lack of information about climate change, high cost of adaptation and insecure property rights.

-results revealed high level of willingness to pay for mitigation policies among the farmers. Years of farming experience, ownership of farm land, farm size and other income are significant predictors of the probability to pay for climate change mitigation policy.

-farmers have perceived increase in temperature, warmer summer temperatures\& colder winter temperatures.

- perceived decrease in rainfall or precipitation, delayed rainfall and early cessation.

- education and awareness about climate change impacts and therefore coping capacities were found to be very low among most farmers partly due to weak institutional coordination and support.

- barriers to adaptation: lack of access to early warning information, unreliability of seasonal forecast \& lack of access to adequate cropland.

\section{Climate Change Perceptions, Adapatations and Barriers in Africa}

The results of the various studies carried out in sub-Sahara Africa to assess farmers' perceptions about adaptations and barriers to adapt to climate change show that the majority of the farmers in Africa; i) are aware of changes in temperature and precipitations, ii) have limited capacity to cope with the adverse consequences of climate change and iii) have barriers to adopt different adaptation strategies. Each of these is elaborated below:

\subsection{Awareness of Climate Change}

Most of the farmers in sub-Sahara Africa are aware of the impact of climate change, especially changes in temperature and precipitation (Acquah-de Graft \& Onumah, 2011; Deressa, et al., 2008; Fosu-Mensah, et al., 2010; Mandleni \& Anim, 2011; Acquah-de Graft, 2011; Akponikpè et al., 2010 etc)

\subsubsection{Temperature}

There is a general consesus among farmers in sub-Sahara Africa that temperature has increased over the years (De Wit, 2006; Acquah-de Graft \& Onumah, 2011; Deressa et al., 2008; Fosu-Mensah et al., 2010; Kurukulasuriya \& Mendelson, 2006; Mandleni \& Anim, 2011, Acquah-de Graft, 2011; Akponikpè et al., 2010; Gandure et al., 2012). However, farmers in southern Africa reported that summer periods are becoming hotter, while winter periods are becoming drier and colder (Gandure et al., 2012; Mandleni \&Amin, 2011; De Wit, 2006). This implies that the annual temperature range in the region has increased. In Zambia, farmers reporetd that they have experenced an 
increase in the duration of the cold season, but no change in the duration of the hot season (Nyanga et al., 2011). Also, in Ethiopia, farmers' reported that temperature and humidity have significantly increased over the years (Yesuf et al., 2008; Deressa et al., 2008). These perceptions about temperature increase in Africa confirms IPPC (2007) predictions about an overall increase in temperature between 0.7 and $3.5^{\circ} \mathrm{C}$ in Africa by 2050 .

\subsubsection{Precipitation or Rainfall}

Farmers' perceptions on precipitation differ in different parts of sub-Sahara Africa. Farmers in southern Africa have generraly reported a decrease in rainfall and a change in the rainfall pattern (Nyanga et al., 2011; Nhemachema \& Hassan, 2007; Gbetibouo, 2009; Mandleni \& Amin, 2011; De Wit, 2006; Gandure, 2012). Some farmers in South Africa reported delayed rainfall and early cessation (Gandure, 2012; Madleni \& Anim, 2011; Gbetibuou, 2009) and others reported reduced precipitation during the crop growing season and abnormal intensive rainfall (Gandure, 2012).

In West Africa, farmers also reported that they have experienced delayed rainfall and early cessation, and excessive rain and strong winds, which sometimes leads to flooding (Apata et al., 2009; Akponikpe et al., 2009; Acquah de Graft \& Onumah, 2011; Mertz et al., 2009). Similar patterns are reported for Egypt in north Africa, Ethiopia and Kenya in East Africa (De Wit, 2006; Yesuf et al., 2008). Farmers in a particular state in Nigeria reported increased temperature and precipitation, and also confirmed changes in the rainfall pattern. That is, delayed rains, intensive and excessive downpour during the crop growing season and early cessation (Sofoluwe et al., 2011).

Empirical results also show that there have been frequent (noticed by the short drought returning period) and extended drought periods in southern and East Africa, which implies no rainfall in these regions for an extended period (Gbetibuou, 2007; Mengistu, 2011; Gandure, 2012; ACCCA, 2010).

Generally, farmers have agreed that the rainfall pattern has changed in sub-Sahara Africa, but they are of the view that both drought (lack of rainfall for a an extended period) and flooding have similar damaging nature (Mertz et al., 2009), and that it is difficult to generally determine the trend of rainfall in sub-Sahara Africa.

\subsection{Perceived Impacts and Adaptations to Climate Change}

Generally, the famers have experienced increased pests and crop diseases, increased crop water requirements, leading to crop failures, reduced crop production in countries or regions where arable farming is predominant (Gbetibuou, 2007; Yesuf et al., 2008; Nyanga et al., 2006; Apkonikpe et al., 2009; Gandure, 2012; Nzeadibe et al., 2011). Livestock farmers reported that the climate change and climate variability have led to decreased livestock weight and an increase in livestock death. These imply loss of farm income and livelihhod for the majority of the rural population; hence, a general deterioration in their welfare (Mengistu, 2009; Sofoluwe et al., 2011; Mandleni $\&$ Amin, 2011; Mertz et al., 2009). Because of these reasons farmers have adopted adaptation measures or coping mechanisms to dampen the adverse effects of climate change.

The adaptation strategies and coping mechanisms adopted by arable farmers in sub-Sahara Africa include:

i. Most farmers in sub-Sahara Africa, especially those in regions with reduced precipitation have swicthed from planting high water-requirement to low water-requirement crops (De Wit, 2006; Yesuf et al., 2008; Nhemachena \& Hassan, 2007; Gandure et al., 2012; Deressa et al., 2008), while crop farmers in regions where floodings are frequent plant short duration crops and have changed the planting and harvesting times to avoid crop growing and harvesting during the intensive rainfall period (Acquah \& de Graft, 2011; Acquah de Graft \& Onumah, 2011; Forsu-Mensah et al., 2010).

ii. Generally, arable farmers have swicted to planting diversified crops, changed planting dates to correspond to the change in the precipitation pattern, planting tree crops, mixed cropping and off-farm income generating activities (Maddison, 2006; Deressa et al., 2008; Fosu-Mensah et al., 2010; Kurukulasuriya \& Mendelson, 2006; Mertz et al., 2009; Sofoluwe et al., 2011, Gandure et al., 2012; Acquah de Graft \& Onumah, 2011; Mengistu, 2009; Nyanga et al., 2006; Gbetibuou, 2007; Sofoluwe et al., 2011)

iii. Farmers in southern Africa and parts of East Africa, where most countries are water stressed, have developed water conservation methods such as water harvesting, waste water re-use in agriculture and crop irrigation (Nyanga et al., 2006; Mengistu, 2009; Deressa et al., 2008; Gbetibuou, 2007; Mertz et al., 2009; Yesuf et al., 2008; Gandure et al., 2012), while farmers in West Africa, where most countries experience short intensive rainy season plant short duration crops, practice upland farming (as opposed to swamp farming) and soil conservation methods (De Wit, 2006; Acquah de Graft, 2011; Apata et al., 2009; Sofoluwe et al., 2011; Kurukulasuriya \& Mendelson, 2006). Some farmers, especially in southern and some parts of 
East Africa have switched from arable to livestock farming (Kurukulasuriya \& Mendelson, 2006; Mengistu, 2009; Deressa et al., 2008).

To cope with or adapt to climate change in sub-Sahara Africa, livestock or pastoral farmers have dug more boreholes in drier regions, switched to off-farm income generating activities and have reduced the number of livestock, by slaughtering and/or selling them during extended drought periods and restocking after the drought (Mandleni \& Anim, 2011; Deressa et al., 2008; Mertz et al., 2009; Gandure et al., 2012). Some other livestock farmers have switched to livestock that can withstand water stress and hot temperatures (Mandleni \& Anim, 2011; De Wit, 2006; Nzeadibe et al., 2011).

\subsection{Barriers to Climate Change Adaptations}

Farmers' ability to cope or adapt to climate change has been challenged by numerous barriers. These include, but not limited to:

i) Institutionl factors: the institutional factors that influence adoption of new technologies are access to information via extension services (climate information and production technologies) and access to credit (Nhemachena \& Hassan, 2008; Maddison, 2006; Acquah-de Graft \& Onumah, 2011; (Deressa et al., 2008; Kurukulasuriya \& Mendelson, 2006; Sofoluwe et al., 2011). The majority of farmers in sub-Sahara Africa found extension education to be an important factor that motivates increased intensity of the use of specific soil and water conservation practices (Gbetibuou, 2007; Mandleni \& Anim, 2011; Deressa et al., 2009; Apata et al., 2009). Farmers expressed the view that among many of the sources of information, agricultural extension is the most important for analyzing the adoption decisions of adaptive measures. Accordingly, it is hypothesized that farmers who have significant extension contacts have better chances of being aware of changing climatic conditions as well as adaptation measures in response to the changes in these conditions (Deressa et al., 2009; Gbetibuou, 2007).

ii) Access to credit is another important factor affecting adoption of agricultural technologies. Access to affordable credit increases financial resources of farmers and their ability to meet transaction costs associated with various adaptation options they might want to adopt (Nhemachena \& Hassan, 2008; ACCCA, 2010; Acquah de Graft \& Onumah, 2011). Hence, access to credit is hypothesized to be a positive and significant factor affecting climate change adaptation measures.

iii) Other barriers to climate change adaptation technologies include; high cost of adaptation measures, insecure property rights (Mandleni \& Anim, 2011; De Wit, 2006; Mengistu, 2009; Nyanga et al., 2006), and land disputes and land fragmentation due topopulation growth in parts of Africa where land is inherited (De Wit, 2006; Deressa et al., 2009).

\subsection{Determinants of Climate Change Adaptation Measures}

Different studies in Africa have used various empirical methods to analyze the socioeconomic determinants of adaptations to climate change in Africa. These methods include discrete choice regression models like the Binomial Probit or Logit (Acquah de Graft \& Onumah, 2011; Fosu-Mensah et al., 2010), and Multinomial Probit or Logit (Nhemachena \& Hassan, 2008; Deressa et al., 2008; ACCCA, 2010; Sofoluwe et al., 2011; Nzeadibe et al., 2011). Other empirical studies used Principal Component Analysis (Mandleni \& Anim, 2011) and the Ricardian Model (Kurukulasuriya \& Mendelson, 2006)

These empirical analyses show that gender, age of farmer, years of farming experience, household size, years of education, access to credit facilities, access to extension services, off-farm income generating activities are among the signicant determinants of adopting climate change adaptation measures (Acquah-de Graft \& Onumah, 2011; Deressa et al., 2008; Fosu-Mensah et al., 2010; Kurukulasuriya \& Mendelson, 2006; Mandleni \& Anim, 2011; Mets et al., 2009).

\section{Summary, Conclusions and Policy Recommendations}

This article reviewed the available existing literature on "Farmers' perceptions and adaptations to climate in sub-Sahara Africa". The review focused on farmers' perceptions on changes in temperature and precipitation (rainfall), adaptation measures taken by farmers, barriers inhibiting these adaptation measures and the socioeconomic determinants of adaptations to climate change in Africa.

The review found out that most farmers in sub-Sahara Africa are aware that the continent is getting warmer, and precipitation or rainfall patterns have changed. However, changes in precipitation patterns are different for different regions in Africa. While farmers in southern and East Africa reported that they have experienced drier conditions with increased frequency of droughts, farmers in West Africa have experienced wetter but shorter rainy season. Observed trends of temperature and precipitation support farmers' perceptions. The implication is that 
farmers need to adjust their agricultural management practices to ensure that they make efficient use of the prevailing precipitation patterns in the different countries or regions.

Important adaptation options being used by farmers include crop diversification, using different crop varieties, changing planting and harvesting dates, increased use of irrigation, planting tree crops increased use of water and soil conservation techniques, and diversifying from farm to non-farm activities.

However, sub-Sahara African farmers strongly believe that the lack of access to information about climate change and adaptation technologies, and access to affordable credit are the main barriers to climate change adaptations. Other barriers to climate change adaptation measures include high cost of adaptation, and insecure property rights in most parts of sub-Sahara Africa.

Different discrete choice models (binomial and multinomial) and other econometric models used in analyzing the socioeconomic determinants of adaptation to climate change show that gender, age of farmers, years of farming experience, household size, years of education, access to creditfacilities, access to extension services and off-farm income are among the signicant determinants of adopting climate change adaptation measures

These findings have both public and private (farm-level) policy implications. At the farm-level, the adaptationoptions being used by farmers can be classified into two main modifications in the production systems. These are (i) increased diversification and (ii) escaping sensitive growth stages through crop management practices thatensure that critical crop growth stages do not coincide with very harsh climatic conditions in the seasonsuch as mid-season droughts in arid and semi-arid countries, and flood in wetter countries.

Increased diversification of crops, through the cultivation of crops that are drought or flood tolerant and resistant to temperature stresses, as well as activities that make efficient use of the prevailing water and temperature conditions, serves as animportant form of climate insurance against rainfall or temperature variability (Nhemachena \& Hassan, 2008). Growing a number of different crops on the same plot or on different plots reduces the risk of complete crop failure as different crops are affected differently by climatic events. It is important to note that these adaptation measures should not be taken as independent strategies but should be used in a complementary way.

At the public policy level, sub-Sahara African governments should include climate change adaptation policies in their development agenda. This should include supporting farmers inincreasing these adaptation measures through the provision of necessary resources such as credit, information and the provision of extension workers to train farmers on climate change adaptation strategies and technologies. There is also the need for governments and non-governmental organizations to invest in climate resilient projects such as improving on existing or building new water infrastructure and building or improving onclimate monitoring and reporting stations. International water transfer agreements between governments of water stressed and water abundant countries should be part of regional strategies to combat regional climate change impacts.

To improve on the existing knowledge on climate change there is the need to conduct further research at local, regional or country levels. The implementation of any climate change policy requires substantial empirical research evidence of the potential costs and benefits of such policy. Therefore, advanced or extensive climate change research is the key to the implementation of regional, national and local climate policy.

\section{References}

ACCCA. (2010). Farm-level climate change perception and adaptation in drought prone areas of Tigray, Northern Ethiopia: in improving decision-making capacity of smallholder farmers in response to climate risk adaptation in three drought prone districts on northern Ethiopia, IDRC Project No093.

Acquah-de Graft, H. (2011). Farmers' perceptions and adaptation to climate change: a willingness to pay analysis. Journal of Sustainable Development in Africa, 13(5), 150-161.

Acquah-de Graft, H., \& Onumah, E. (2011). Farmers' perceptions and adaptations to climate change: An estimation of willingness to pay. Agris, 3(4), 31-39.

AFP, (2007). Climate Change and Africa. $8^{\text {th }}$ Meeting of African Partnership Forum, Berlin, Germany, 22-23 May, 2007.

Akponikpe, P., Johnston, P., \& Agbossou, E. K. (2010). Farmers' perceptions of climate change and adaptation strategies in sub-Sahara West Africa. $2^{\text {nd }}$ International Conference on Climate, Sustainability and Development in Arid Regions, Fartaleza-Ceara, Brazil. 
Apata, T. G., Samuel, K. D., \& Adeola, A. O. (2009). Analysis of climate change perceptions and adaptation among arable food crop farmers in South Western Nigeria. Contributed paper presented at $23^{\text {rd }}$ Conference of International Association of Agricultural Economists, Beijing, China, August 16-22, 2009.

Arnell, N. W. (2004). Climate change and global water resources: SRES emissions and socio-economic scenarios. Global Environmental Change, 14(1), 31-52.

Conway, G. (2008). The Science of Climate Change in Africa: Impacts and Adaptation. DFID. Retrieved from http://www.elsenburg.com/trd/globalwarm/downloads/science.pdf.accessed on 25/12/2012

de Wit, M. (2006). The perception of and adaptation to climate change in Africa, CEEPA discussion Paper No. 10, CEEPA, University of Pretoria.

Deressa, T., Hassan, R., Ringler, C., Alemu, T., \& Yesuf, M. (2008). Analysis of the Determinants of Farmers' Choice of Adaptation Methods and Perceptions of Climate Change in the Nile Basin of Ethiopia. IFPRI Discussion Papers No. 798, International Food Policy Research Institute, Washington DC.

FAO. (2009). Climate Change in Africa: The Threat to Agriculture. Retrieved from $\mathrm{ftp} / / / \mathrm{ftp}$.fao.org/docrep/fao/012/ak915e/ak915e00.pdf.Accessed on 25/12/2012

FAO. (2007). Food and Agricultural Organization of the United Nations. Retrieved from www.fao.org/nr/water/aquastat/countries/botswana/index.stm

Fosu-Mensah, B., Vlek, P., \& Manschadi, M. (2010). Farmers' Perceptions and Adaptations to Climate Change: A Case Study of Sekyedumase District in Ghana. A contributed paper presented at World Food Systems Conference in Tropentag, Zurich: $14^{\text {th }}-16$ September, 2010.

Gandure, S., Walker, S., \& Botha, J. J., (2012). Farmers'perceptions of adaptation to climate change and water in a South African rural community. Environment Development. Retrieved from http://dx.doi.org/10.1016/j.endev.2012.11.004

Gbetibouo, G. (2009). Understanding Farmers' Perceptions and Adaptations to Climate Change and Variability, the Case of the Limpopo Basin, South Africa: IFPRI Discussion paper 00849.

Glantz, M. H. (1992). Global Warming and Environmental Change in sub-Saharan Africa. Global Environmental Change, 2, 183-204.

Hulme, M. (1994). Regional climate change scenarios based on IPCC emissionsprojections with some illustrations for Africa. Area, 26, 33-44.

IPCC. (2007). Summary for Policymakers. In M. L. Parry, O. F. Canziani, J. P. Palutikof, P. J. van der Linden, \& C. E. Hanson (Eds.), Climate Change 2007: Impacts, Adaptation and Vulnerability. Contribution of Working Group II to the Fourth Assessment Report of the Intergovernmental Panel on Climate Change. Cambridge, UK and New York, NY, USA: Cambridge University Press.

IPCC. (2001). Climate Change 2001: Impacts, Adaptation and Vulnerability. In J. J. McCarthy, O. F. Canziani, N. A. Leary, D. J. Dokken, \& K. S. White (Eds.), IPCC Working Group II, Third Assessment Report. Cambridge University Press.

Juana, J. S., Mangadi, K. T., \& Strzepek, K. M. (2012). The socioeconomic impacts of climate change on water resources in South Africa. Water International, 37(3), 265-278. http://dx.doi.org/10.1080/02508060.2012.687505

Juana, J. S., Makepe, P. M., \& Mangadi, K. T. (2012). Empirical analysis of the impact of drought on the Botswana economy, Presented at the AERC/UNU-WIDER Climate Change Workshop, Helsinki, 25-29 September, 2012.

Kurukulasuriya, P., \& Mendelson, R. (2006). Crop Selection: Adapating to Climate Chnage in Africa. IFPRI, Environment and Production Technology Division. Washington, DC: International Food Policy Research Institute.

Lovejoy, T. E. (2005). Conservation with a changing climate. In T. E. Lovejoy, \& L. Hannah (Eds.), Climate Change and Biodiversity. New Haven \& London, UK: Yale University Press.

Maddison, D. (2006). The perception and adaptation to climate change in Africa. CEEPA. Discussion paper No.10. Centre for Environmental Economics and Policy in Africa. Pretoria, South Africa, University of Pretoria.

Mandleni, B., \& Anim, F. (2011). Perceptions of Cattle and Sheep Framers on Climate Change and Adaptations in the Eastern Cape Province of South Africa. Journal of Human Ecology, 34(2), 107-112. 
Mengistu, D. K. (2011). Farmers' perception and knowledge of climate change and their coping strategies to the related hazards: Case study from Adiha, central Tigray, Ethiopia. Agricultural Sciences, 2(2), 138-145.

Mertz, O., Mbow, C., Reenberg, A., \& Diouf, A. (2009). Fermers' Perceptions of Climate Change and Agricultural Adaptation Strategies in Rural Sahel. Environmental Management, 43(2009), 804-816.

Mwingira, C. E., Pallangyo, M. E., Felix, R., Pima, N., Meingataki, G., \& Salum, S. (2011). Impacts of Climate Change on Biodiversity and Community Livelihoods in the Katari Ecosystem. International START Secretariat. Washington, DC.

Nhemachena, C., \& Hassan, R. (2007). Micro-level Analysis of Farmers' Adaptations to Climate Change in Southern Africa. IFPRI, Environment and Production Technology Division. Washington, DC: International Food Policy Research Institute.

Nyanga, P., Johnsen, F., Aune, J., \& Kahinda, T. (2011). Smallholder Farmers' Perceptions of Climate Change and Conservation Agriculture: Evidence from Zambia. Journal of Sustainable Development, 4(4), 73-85. http://dx.doi.org/10.5539/jsd.v4n4p73

Nyong, A. (2005). Key Vulnerabilities to climate change in Africa: in Global warming: Looking beyond Kyoto. Yele Centre for Study of Globalization 21-22 October, 2005. Retrieved from http://www.ycsg.yale.edu/climate/forms/Nyong_Yale.pdf . Accessed 13/12/2012

Nzeadibe, T. C., Egbule, C. L., Chukwuone, N., \& Agu, V. (2011). Farmers' Perceptions of Climate Change Governance and Adaptation Constraints in Niger Delta Region of Nigeria. African Technology Policy Network, Research Paper No. 7.

Shiklomanov, I. A. (1997). Assessment of Water Resources and Water Availability in the World. World Meteorological Organization.

Sofoluwe, N., Tijani, A., \& Baruwa, O. (2011). Farmers' Perception and Adaptations to Climate Change in Osun Satte, Nigeria. African Journal of Agricultural Research, 6(20), 4789-4794.

Yesuf. M, Di Falco. S., Deressa, T., Ringler. C., \& Kohlin. G. (2008). The Impact of Climate Change and Adaptation on Food Production in Low-Income Countries: Evidence from the Nile Basin, Ethiopia, EDRI. 